\title{
Prognostic features of large cell anaplastic carcinoma of the bronchus
}

\author{
D M MITCHELL, P G M MORGAN, AND J B BALL
}

From the Brompton Hospital, London

ABSTRACT The clinical features of 208 patients with large cell anaplastic carcinoma of the bronchus are reviewed. Of the sample $47.6 \%$ had disseminated disease at presentation, and $95 \%$ were cigarette smokers. The median survival was 6.0 months and five-year-survival was $5.9 \%$. Twenty-seven per cent of the patients had surgical resection of tumour. The median survival of resected patients was 13.0 months and five-year-survival was $21 \%$. Radiotherapy was ineffectiv® in controlling the disease in this series.

Large cell carcinoma of the bronchus accounts for $7-14 \%$ of all bronchogenic carcinomas. ${ }^{1-3}$ In 1948 Willis $^{4}$ proposed a unitary view of bronchogenic carcinoma as he found that in a series of 84 cases, $19(23 \%)$ had features of more than one cell type. A different conclusion was reached by Walter and Pryce ${ }^{3}$ who reviewed 207 resection specimens and material from 159 postmortems. They divided the tumours into oat cell, squamous cell, adenocarcinoma, and a fourth anaplastic group that lacked squamous or glandular features and that did not resemble oat cell carcinoma. They suggested that this group might represent either anaplastic squamous carcinoma or adenocarcinoma. They found no convincingly mixed tumours. The cellular variability they did find in individual tumours was the result of secondary change within the tumour, and they concluded that histological types of bronchogenic carcinoma were distinct and not degrees of a spectrum.

For practical purposes a modified World Health Organisation classification ${ }^{5}$ is used by most histopathologists, the four common tumours being epidermoid, adenocarcinoma, small cell anaplastic carcinoma, and large cell carcinoma. This last group consists of large undifferentiated cells lacking features of the other three common tumours and lacking the special features of the rare pulmonary neoplasms. Prognosis and response to treatment depend on the histological type of tumour, ${ }^{67}$ and although there are many general large retrospective studies of bronchogenic car-

Address for reprint requests: Dr DM Mitchell, Brompton Hospital, Fulham Road, London SW3 6HP. cinoma, 289 the natural history of each histologicaP type is often not described separately. This is particularly so for large cell carcinoma which is usually considered together with small cell caro cinoma. This is inappropriate, as small celfू carcinoma is now understood to have a distinct cell of origin and biological behaviour. ${ }^{1011}$ Or $\vec{B}$ the other hand prospective studies of various treatments for carcinoma of the bronchus have focused attention on epidermoid, adeno, and smalP. cell carcinoma of the bronchus.

This study was, therefore, undertaken to clarif the natural history of large cell carcinoma of the bronchus.

\section{Methods}

Case records of all patients with a diagnosis of large cell, anaplastic, or unclassified carcinoma op the bronchus were selected and the histology was. reviewed.

Two hundred and eight patients with large celf carcinoma were diagnosed at Brompton Hospitad from September 1968 to September 1978. This represents approximately $9 \%$ of all classifie $\bar{P}$ bronchogenic carcinomas diagnosed during that period. They were followed from first admissioro until death or until September 1978. Fifteen were lost to follow-up. Histology was reviewed by consultant histopathologist (JB) and only case fulfilling the following criteria were included: (1\$ cells greater than $12 \mu \mathrm{m}$ in diameter; (2) no evio dence of keratinisation; (3) no evidence of tubule formation or mucin production; (4) the sample 
examined was considered adequate to exclude the possibility of differentiation elsewhere in the tumour; (5) no features of the rare pulmonary neoplasms.

\section{Clinical features}

One hundred and fifty-nine patients were men and 49 were women, the male to female ratio being $3 \cdot 2: 1$. The age range was from 36 to 82 years with a mean age of 59.6 years; $79.3 \%$ were between 50 and 70 years old. The mean ages for women and men were 56.8 years and 60.9 years respectively. Eleven of the patients stated that they were non-smokers and information on smoking was not available in a further seven. Of the smokers $9.4 \%$ smoked up to 10 cigarettes a day, $17 \cdot 4 \%$ smoked $10-20$ a day, $38.5 \%$ smoked $20-30$ a day, $13.9 \% 30-40$ a day, and $20.8 \%$ smoked in excess of 40 a day. The mean number of cigarettes smoked was 24.5 per day. At diagnosis, 159 had not stopped smoking, 26 gave up smoking over one year before diagnosis, and 16 gave up during the year before diagnosis. There was no record of asbestos exposure in any of the patients; 26 worked in the engineering or electrical industries.

The symptoms are summarised in table 1. Only nine patients $(4 \cdot 3 \%)$ were asymptomatic. Of the $41(19.7 \%)$ patients who had other symptoms not mentioned in the table, seven had malaise, three

\section{Table 1 Symptomatology of large cell carcinoma}

\begin{tabular}{ll}
\hline Symptoms & $\begin{array}{l}\text { Patients } \\
\text { affected } \\
(\%)\end{array}$ \\
\hline Cough & $61 \cdot 5$ \\
Chest pain & $48 \cdot 0$ \\
Short of breath & $44 \cdot 2$ \\
Sputum & $35 \cdot 5$ \\
Haemoptysis & $30 \cdot 2$ \\
Weight loss & $27 \cdot 4$ \\
Other symptoms & $19 \cdot 7$ \\
Upper respiratory tract infection & $8 \cdot 6$ \\
Asymptomatic & $4 \cdot 3$ \\
\hline
\end{tabular}

Table 2 Physical signs in large cell carcinoma

\begin{tabular}{ll}
\hline Sign & $\begin{array}{l}\text { Patients } \\
\text { affected } \\
(\%)\end{array}$ \\
\hline Chest signs (wheeze, crackles, effusion, etc.) & $61 \cdot 6$ \\
Cervical lymph node enlargement & $27 \cdot 5$ \\
No physical signs & $22 \cdot 6$ \\
Hepatomegaly & $17 \cdot 8$ \\
Clubbing & $17 \cdot 4$ \\
Pleural effusion & $13 \cdot 0$ \\
Superior vena cava obstruction & $5 \cdot 7$ \\
Central nervous system signs & $4 \cdot 8$ \\
\hline
\end{tabular}

had hoarseness, three complained of lumps in the neck, five had cerebral symptoms, two had dysphagia, one had abdominal pain, one had hypertrophic pulmonary osteoarthropathy, and one had fever.

The physical findings are summarised in table 2 . One patient had a metastasis in the orbit. There were no cases of carcinomatous neuromyopathy. Only three $(1.4 \%)$ patients had clinical evidence of bone involvement.

\section{Investigations}

Chest radiography revealed a right-sided abnormality in 112 patients $(54 \%)$, and of these, 62 $(30 \%)$ also had mediastinal involvement. Leftsided abnormality was present in 91 patients $(44 \%)$ and $52(25 \%)$ of these also had mediastinal involvement. Two patients had a normal chest radiograph, one had bilateral changes, and in two the records were lost. Twenty-three $(14.2 \%)$ of 161 patients had positive sputum cytology. One hundred and forty-three patients had bronchoscopy and there was a visible abnormality in $88(61.5 \%)$.

Seventy-two $(71 \%)$ patients had an $\mathrm{FEV}_{1} / \mathrm{FVC}$ ratio of less than $75 \%$. Liver scintiscans were performed in 31 patients and were abnormal in four; two of them had an enlarged liver on palpation, and the other two had abnormal liver function tests. Bone scintiscans were performed in 19 patients. Of these, 12 had bone pain, and of these six had abnormal scans. Brain scintiscans were performed in eight patients, five of whom had central nervous system symptoms or signs. Only one scan was abnormal.

Forty-four (22.5\%) patients out of 195 had a haemoglobin of less than 12 g. Fifty-five (29.7\%) had a total WBC of less than $5 \times 10^{9} / 1$, and 23 $(13.5 \%)$ had a count of greater than $10 \times 10^{9} / 1$. Seventy-five $(48 \%)$ had a relative lymphocyte count of less than $20 \%$. Eight $(5 \cdot 1 \%)$ patients had a relative monocyte count of greater than $10 \%$. One hundred and seventeen patients $(68.8 \%)$ had an ESR of greater than $20 \mathrm{~mm}$ in one hour. Only one patient had a plasma sodium level of below $125 \mathrm{mEq} / 1,37(20.3 \%)$ had plasma sodium below $132 \mathrm{mEq} / 1$ (normal range $132-145 \mathrm{mEq} / \mathrm{l}$ ). Nineteen $(10.4 \%)$ had plasma potassium below 3.5 $\mathrm{mEq} / \mathrm{l}$. Serum calcium was below $2 \cdot 2 \mathrm{mEq} / 1$ in three $(4 \%)$ of 72 patients, and above $2.6 \mathrm{mEq} / 1$ in $11(15 \%)$. Liver function tests as measured by alkaline phosphatase, gamma glutamyl transpeptidase, and aspartate transaminase were measured in 123 patients; $83(67 \%)$ were normal, $34(27.6 \%)$ had a rise in alkaline phosphatase alone, and six 
$(4.8 \%)$ had raised values for all three enzymes. The mode of diagnosis is summarised in table 3.

At presentation each patient was placed in one of three groups: (1) disease confined to one hemithorax without lymph node involvement; (2) unilateral thoracic disease with mediastinal lymph node involvement; (3) extensive disease (including chest wall involvement). Stage at presentation and extent of disease at death are summarised in table 4. Post-mortem examination was performed in 24

Table 3 Method of diagnosis in large cell carcinoma

\begin{tabular}{lc}
\hline Method & $\begin{array}{l}\text { Patients } \\
(\%)\end{array}$ \\
\hline Bronchoscopy & $42 \cdot 3$ \\
Thoracotomy & $20 \cdot 1$ \\
Supraclavicular node biopsy & $19 \cdot 7$ \\
Percutaneous needle biopsy & $3 \cdot 3$ \\
Mediastinotomy & $3 \cdot 3$ \\
Sputum cytology alone & $3 \cdot 1$ \\
Pleural biopsy & $2 \cdot 9$ \\
Mediastinoscopy & $2 \cdot 4$ \\
Postmortem & $2 \cdot 4$ \\
Drill biopsy & $0 \cdot 5$ \\
\hline
\end{tabular}

Table 4 Spread of disease in large cell carcinoma

\begin{tabular}{ll}
\hline Spread of disease & $\begin{array}{l}\text { Patients } \\
(\%)\end{array}$ \\
\hline At presentation & \\
Stage 1 Local disease & $19 \cdot 2$ \\
Stage 2 Local disease with mediastinal involvement & $33 \cdot 1$ \\
Stage 3 Extensive disease & $47 \cdot 6$ \\
At death & \\
Local disease in the chest & $93 \cdot 7$ \\
Lymph node involvement & $90 \cdot 1$ \\
Liver involvement & $62 \cdot 3$ \\
Bone involvement & $55 \cdot 9$ \\
Central nervous system involvement & $54 \cdot 3$ \\
Skin metastases & $4 \cdot 4$ \\
\hline
\end{tabular}

patients and three $(12.5 \%)$ had adrenal involve $\frac{\infty}{\circ}$ ment.

\section{Survival}

Survival figures as actuarial survival were calcu望 lated by the life table method. The median surviva 5 for the whole group was 6.0 months. One-yearsurvival was $27.9 \%$, and five-year-survival waș $5.9 \%$ for the whole group. Shortened surviva? (Spearman's rank correlation coefficient) corre $x$ lated with the features listed in table 5. Symptoms

Table 5 Factors affecting survival in large cell carcinoma

\begin{tabular}{lcl}
\hline Shortened survival correlated with & p value \\
\hline Lymph node enlargement & $<0.001$ \\
Abnormal chest signs & $<0.001$ \\
Elevated ESR & $<0.001$ \\
Elevated WBC & $<0.001$ \\
Decreased lymphocyte count & $<0.005$ \\
Abnormal liver function tests & $<0.005$ \\
Raised polymorph count & $<0.025$ \\
Increasing age & $<0.05$ \\
Low haemoglobin & $<0.05$ \\
Weight loss & $<0.05$ \\
\hline
\end{tabular}

did not correlate with survival, apart from weigh loss. There was no difference in survival betweer patients with peripheral lung opacity alone an those with lung opacity and mediastinal involve 3 ment. Survival figures are compared between those with disease limited to the chest, and those witp clinical evidence of dissemination-namely, lymph node enlargement, palpable liver, superior venæ cava obstruction, pleural effusion, bone involve ment, or central nervous system involvement. Suro vival data are summarised in table 6 .

Table 6 Survival of patients with large cell carcinoma

\begin{tabular}{|c|c|c|c|c|c|c|c|c|c|}
\hline \multirow[b]{2}{*}{ Group } & \multirow[b]{2}{*}{ Number } & \multirow[b]{2}{*}{$\begin{array}{l}\text { Mean age } \\
(y r)\end{array}$} & \multicolumn{2}{|c|}{ Disease staging } & \multicolumn{4}{|c|}{$\%$ Survival } & \multirow{2}{*}{$\begin{array}{l}\text { Median } \\
\text { survival } \\
\text { (months) }\end{array}$} \\
\hline & & & $\begin{array}{l}\text { Stage } \\
1+2\end{array}$ & $\begin{array}{l}\text { Stage } \\
3\end{array}$ & $4 m o$ & $6 \mathrm{mo}$ & $12 \mathrm{mo}$ & $5 y r$ & \\
\hline $\begin{array}{l}\text { Untreated } \\
\text { Radiotherapy } \\
\text { Palliative }\end{array}$ & $\begin{array}{l}58 \\
45\end{array}$ & $\begin{array}{l}62 \cdot 6 \\
58\end{array}$ & $\begin{array}{l}21(36 \%) \\
24(53 \%)\end{array}$ & $\begin{array}{l}37 \\
21\end{array}$ & $\begin{array}{l}37 \\
65 \cdot 5\end{array}$ & $\begin{array}{l}25 \cdot 4 \\
46 \cdot 8\end{array}$ & $\begin{array}{l}11 \\
18 \cdot 8\end{array}$ & $\begin{array}{l}0 \\
0\end{array}$ & $\begin{array}{l}2 \cdot 5 \\
6 \cdot 0\end{array}$ \\
\hline radiotherapy & 28 & 59 & $8(29 \%)$ & 20 & $64 \cdot 3$ & $44 \cdot 2$ & $20 \cdot 2$ & 0 & 5.9 \\
\hline Surgery & 55 & 58 & $42(76 \%)$ & 13 & $78 \cdot 1$ & $70 \cdot 6$ & $53 \cdot 5$ & $21 \cdot 2$ & $13 \cdot 0$ \\
\hline Chemotherapy & 8 & 60 & $0(0 \%)$ & 8 & - & - & - & - & $\begin{array}{l}4.4 \\
\text { (range 1.4 } \\
12 \cdot 0 \text { ) }\end{array}$ \\
\hline $\begin{array}{l}\text { Chemotherapy } \\
\text { and } \\
\text { radiotherapy }\end{array}$ & 4 & 61 & $0(0 \%)$ & 4 & - & - & 一 & - & $\begin{array}{l}2.9 \\
\text { (range 2- } \\
16.4)\end{array}$ \\
\hline $\begin{array}{l}\text { Surgery and } \\
\text { radiotherapy }\end{array}$ & 4 & 60 & $4(100 \%)$ & 0 & - & - & 一 & 一 & $\begin{array}{l}6 \cdot 2 \\
\text { (range 6- } \\
19 \cdot 8 \text { ) }\end{array}$ \\
\hline All groups & 202 & $59 \cdot 6$ & 99 & 103 & $60 \cdot 7$ & $46 \cdot 6$ & $27 \cdot 9$ & $5 \cdot 9$ & $6 \cdot 0$ \\
\hline
\end{tabular}




\section{Treatment}

\section{UNTREATED}

Fifty-eight patients $(28.7 \%)$ received no treatment, either because they were too ill, or physician or patient decided against treatment. None of these patients was asymptomatic. Twenty-one (36\%) had no clinical evidence of dissemination, and $37(63 \%)$ had extrathoracic disease. The median survival was 2.5 months (range four days to 21.2 months), one-year-survival was $11.0 \%$, and fiveyear-survival was zero. There was no difference in median survival between those with and those without disseminated disease.

\section{RADIOTHERAPY}

Forty-five patients $(22.3 \%)$ received radiotherapy to the primary lesion and the mediastinum if this was also involved. Doses ranged from 3500 to 5000 rads. Twenty-four patients $(53 \%)$ had limited disease (stage 1 and 2 ) and $21(46 \%)$ had clinical evidence of dissemination. The median survival of the whole group was 6.0 months (range 20 days to 47 months). Median survival for limited disease was 6.2 months, and for extensive disease $4 \cdot 1$ months. One-year-survival was $18 \cdot 8 \%$, five-yearsurvival was zero.

\section{PALLIATIVE RAIIOTHERAPY}

Twenty-eight patients $(13.9 \%)$ received palliative radiotherapy. Twenty had clinical evidence of dissemination (stage 3). Median survival was 5.9 months (range: nine days to $19 \cdot 4$ months), oneyear-survival was $20.2 \%$, five-year-survival was zero. Those with disseminated disease had a median survival of 4.7 months and those with limited disease $6 \cdot 6$ months.

\section{SURGERY}

Eighty-four patients (41\%) underwent thoracotomy; 29 were found to be inoperable and 55 $(27 \cdot 2 \%)$ underwent pneumonectomy or lobectomy. Thus $34.5 \%$ of patients submitted to surgery were inoperable. The 29 inoperable patients either had radiotherapy or no further treatment. Of the group that had resections, $41(74.5 \%)$ had limited disease (stage 1 and 2 ) and $14(25.5 \%)$ had extensive disease (stage 3 ). There was no significant difference in age between surgical treatment and no treatment. The median survival was 13 months (range: 14 days to 3900 days), one-year-survival was $53 \cdot 5 \%$, and five-year-survival $21 \cdot 2 \%$.

\section{CHEMOTHERAPY}

Eight patients received chemotherapy. A variety of drug combinations was used. Median survival was 4.4 months (range: 1.4 to 12.0 months).

\section{RADIOTHERAPY AND CHEMOTHERAPY}

Four patients received combination treatment. Median survival was 2.9 months (range: 2 to 16.4 months).

\section{SURGERY AND RADIOTHERAPY}

Four patients received postoperative radiotherapy. Median survival was 6.2 months (range: 6 to $19 \cdot 8$ months).

Treatment records were unavailable in a further six patients.

\section{Survival and treatment}

There was a statistically significant difference in survival between radiotherapy to the primary lesion and mediastinum, and patients receiving no treatment $(<0.05$, Mann-Whitney $U$ test $)$, but no statistically significant difference between palliative radiotherapy and patients receiving no treatment was observed. The difference in survival between patients receiving no treatment and those receiving surgery was highly significant $(<0 \cdot 001)$. The numbers in the other treatment groups were too small to allow statistical analysis.

\section{Discussion}

Ninety-five per cent of the patients in our series were smokers suggesting that large cell carcinoma is a smoking related disease. The age distribution was similar to other series of all histological types although women (mean age 56 years) were significantly younger than men (mean age 61 years) $(<0.002)$. Four per cent of patients were asymptomatic. In those with symptoms $50 \%$ had dull intermittent chest pain and nearly one-third had haemoptysis. There were no physical signs in $23 \%$ at presentation. This may reflect the tendency of the disease to arise in the lung periphery ${ }^{12}{ }^{13}$ Clinically, bone and CNS involvement were rare at presentation but common at death. Ninety-eight per cent of patients had an abnormality on chest radiograph and of these $43 \%$ had a peripheral abnormality alone. This confirms Byrd's and colleagues finding of a solitary peripheral abnormality in $40 \%$ of 93 patients with large cell carcinoma, in contrast to squamous cell carcinoma where only $24 \%$ had peripheral abnormality alone. ${ }^{12}{ }^{13}$ In our series, site and extent of chest radiograph abnormality did not affect survival. Forty-two per cent were diagnosed at 
bronchoscopy and $14 \%$ had positive sputum cytology. These figures are low compared with series of other histological types and may reflect the peripheral nature of the disease, and, in the case of sputum cytology, ${ }^{14}$ possibly large cell carcinoma does not exfoliate as readily as epidermoid and small cell carcinoma.

The five-year-survival figure for the whole group of $5.9 \%$ is lower than that reported for squamous carcinoma or adenocarcinoma, ${ }^{67}$ but similar to that reported for small cell carcinoma. ${ }^{11}$ The median survival for patients who received no treatment was 2.5 months, similar to small cell carcinoma, $2 \cdot 3$ months, and survival was not affected by staging at presentation. This group cannot be used as a control as they were a selected group either because they were too ill to receive treatment, declined treatment, or were found to be inoperable at thoracotomy. Radiotherapy produced very poor survival figures. Large cell carcinoma has been reported to be more radiosensitive than epidermoid or adenocarcinoma. ${ }^{15}$ It is, therefore, surprising that there were no five-year radiotherapy survivors, as long-term survival has been reported with epidermoid and small cell carcinoma. ${ }^{16}$ Radiotherapy prolonged survival when compared with untreated patients but, as already pointed out, the untreated group cannot be used as a control, and treatment with radiotherapy presupposes a minimum of four weeks survival from diagnosis. The poor radiotherapy results in this series suggest that the tumour is not very radiosensitive.

No conclusion can be drawn from the chemotherapy group because of the small numbers of patients and varied drug regimens used. However, large cell carcinoma has similarities with small cell carcinoma (which has been reported to be responsive to chemotherapy ${ }^{17}$ ) as the untreated survival time is short, and both are disseminated in the majority of cases at presentation.

In $27 \%$ of patients it was possible to resect tumour surgically. These patients had a five-yearsurvival of $21 \%$ which compares favourably with epidermoid carcinoma ${ }^{6} 18$ and offers the only possibility of useful survival.

\section{References}

1 Auerbach O, Garfinkel L, Parks VR. Histologic $\frac{\bar{\sigma}}{\bar{D}}$ types of carcinoma in relation to smoking habits, $\vec{\odot}$ year of diagnosis and sites of metastases. Chest $\stackrel{0}{2}$ 1975; 67:382-7.

2 Le Roux BT. Bronchial carcinoma. Thorax 1968; 23:136-43.

3 Walter JB, Pryce DM. The histology of lung $\vec{\omega}$ cancer. Thorax 1955; 10:107-16.

4 Willis RA. Pathology of tumours. London: $\frac{\vec{x}}{x}$ Butterworth Medical Publications, 1948.

5 Kreyberg L. Histological typing of lung tumours. Or International histological classification of tumours, no 1. Geneva: World Health Organization, 1967. $\overrightarrow{\vec{\infty}}$

6 Goldman KP. Histology of lung cancer in relation to prognosis. Thorax 1965; 20:298-302.

7 Hyde L, Yee J, Wilson R, Patno ME. Cell type and the natural history of lung cancer. JAMA 1965; 193:140-2. 8 Bignall JR. Carcinoma of the lung. Edinburgh:@

9 Hyde L, Hyde CI. Clinical manifestations of lung $\overrightarrow{0}$ cancer. Chest 1974; 65:299-306.

10 Azzopardi JG. Oat-cell carcinoma of the bronchus. J Pathol Bacteriol 1959; 78:513-9.

11 Morgan PGM. Oat cell carcinoma, 230 cases. A review. In preparation.

12 Byrd RB, Miller WE, Carr DT, Payne WS, ֶ Woolner LB. Roentgenographic appearance of $\mathbb{D}^{\mathbb{Q}}$ squamous cell carcinoma of the bronchus. Mayo $\overrightarrow{\vec{A}}$ Clin Proc 1968; 43:327-33.

13 Byrd RB, Miller WE, Carr DT, Payne WS, Woolner LB. Roentographic appearance of large cell carcinoma of the bronchus. Mayo Clin Proc 1968; 43:333-6.

14 Erozan YS, Frost JK. Cytopathologic diagnosis of lung cancer. Semin Oncol 1974; 1:191-8.

15 Salazar OM, Rubin P, Brown JC, Feldstein ML, 을 Keller BE. Prediction of radiation response in lung cancer. A clinico-pathobiological analysis. Cancer 1976; 37:2636-50.

16 Smart J. Can lung cancer be cured by irradiation윽 alone? JAMA 1966; 195:1034-5.

17 Cohen MH, Creaven PJ, Fossieck BE et al. In-Oㅡㅡ. tensive chemotherapy of small cell bronchogenic carcinoma. Cancer Treat Rep 1977; 61:349-54.

18 Morrison R, Deeley TJ, Cleland WP. The treat- N ment of carcinoma of the bronchus. A clinicaln trial to compare surgery and supervoltage radiotherapy. Lancet 1963; 1:683-4. 